\title{
ANALISIS KEJADIAN EL NINO DAN PENGARUHNYA TERHADAP INTENSITAS CURAH HUJAN DI WILAYAH JABODETABEK (Studi Kasus : Periode Puncak Musim Hujan Tahun 2015/2016)
}

\author{
Analysis of El Nino Event and Its Influence to Rainfall Intensity \\ in the Jakarta-Bogor-Depok-Tangerang-Bekasi Area \\ (Case Study : Rainy Season Peak Period In 2015/2016)
}

\author{
Ardila Yananto ${ }^{1)^{*}}$, Rini Mariana Sibarani $i^{2)}$ \\ ${ }^{1,2)}$ Balai Besar Teknologi Modifikasi Cuaca - Badan Pengkajian dan Penerapan Teknologi, Gedung Ir. \\ Mohammad Soebagio, GEOSTECH (820), Kawasan PUSPIPTEK, Serpong, Tangerang Selatan \\ *E-mail : ardila.yananto@bppt.go.id
}

\begin{abstract}
Intisari
Beberapa lembaga riset dunia dan badan-badan meteorologi beberapa negara di dunia menyatakan adanya kejadian El Nino Tahun 2015 terus berlanjut hingga tahun 2016. Adanya kejadian El Nino tersebut secara umum akan mempengarui intensitas curah hujan di sebagian besar wilayah Indonesia termasuk wilayah Jabodetabek. Analisis kejadian El Nino Tahun 2015/2016 dilakukan dengan menganalisis nilai NINO 3.4 SST Index, Southern Oscillation Index (SOI), Indian Ocean Dipole (IOD), pola sebaran suhu permukaan laut (Sea Surface Temperature) dan juga gradient wind di Samudra Pasifik Tropis. Sedangkan Analisis Curah Hujan dilakukan dengan menggunakan data TRMM (Tropical Rainfall Measuring Mission). Dari penelitian ini dapat diketahui bahwa berdasarkan parameter NINO 3.4 SST Index dan Southern Oscillation Index (SOI) pada pertengahan Tahun 2015 hingga awal Tahun 2016 telah terjadi fenomana El Nino pada level kuat, adanya peningkatan suhu permukaan laut di sebagian besar wilayah Indonesia sejak Bulan November 2015 yang diikuti dengan penurunan indeks Dipole Mode hingga menjadi bernilai negatif (-) sejak awal Tahun 2016 serta dengan adanya peralihan Angin Muson Timur ke Angin Muson Barat di wilayah Indonesia telah menyebabkan peningkatan curah hujan yang cukup signifikan dalam batas normal di wilayah Jabodetabek pada puncak musim hujan Tahun 2015/2016 (November 2015 - Februari 2016) walaupun pada Bulan November 2015 hingga Februari 2016 tersebut masih berada pada level El Nino kuat.
\end{abstract}

Kata Kunci : El Nino, Suhu Permukaan Laut, Gradient Wind, Intensitas Curah Hujan.

\begin{abstract}
Various research institutions in the world that work in the field of Meteorology and Climatology predicted an El Nino events in 2015 continued into 2016. The El Nino events phenomenon in general will affect to intensity of the rainfall in most parts of Indonesia, including the Greater Jakarta area. El Nino events phenomenon Analysis by Nino 3.4 SST index, Southern Oscillation Index (SOI), Indian Ocean Dipole (IOD), Sea Surface Temperature (SST) and gradient wind in the Tropical Pacific Ocean. While rainfall intensity analysis using TRMM (Tropical Rainfall Measuring Mission) data. From this research it is known that based on the parameters NINO 3.4 SST index and the Southern Oscillation Index (SOI), it is known that there was a strong El Nino event occurred in mid-2015 to early 2016, the increase of sea surface temperature in most parts of Indonesia since November 2015 followed by declines Dipole Mode Index to be negative (-) since the beginning 2016 as well as the shift East monsoon to West monsoon in Indonesia has led to significant rainfall increased within normal limits in the Greater Jakarta area at the peak period of the rainy season 2015/2016 (November 2015 - February 2016) although in November 2015 until February 2016 El Nino event is still at the strong level.
\end{abstract}

Keywords : El Nino, Sea Surface Temperature, Gradient Wind, Rainfall Intensity.

\section{PENDAHULUAN}

Sebagai negara kepulauan yang terletak di antara samudra Hindia dan Samudra Pasifik curah hujan di Indonesia sangat dipengarui oleh perubahan suhu permukaan laut disekelilingnya. Ketika terjadi peningkatan suhu permukaan laut di bagian Tengah dan Timur Samudra Pasifik sekitar equator yang dikenal dengan El Nino hal tersebut berhubungan dengan penurunan curah 
hujan di Indonesia. Begitu juga sebaliknya ketika terjadi penurunan suhu permukaan laut di bagian Tengah dan Timur Samudra Pasifik sekitar equator atau yang lebih dikenal dengan La Nina berhubungan dengan peningkatan curah hujan di Indonesia (Mulyana, 2002).

Wilayah Jabodetabek pada umumnya dan DKI Jakarta pada khususnya merupakan wilayah yang identik dengan banjir di saat memasuki periode puncak musim penghujan setiap tahunnya. Salah satu faktor utama penyebab banjir Jakarta tersebut adalah durasi dan besaran intensitas curah hujan (Gunawan, 2010). Beberapa kasus terburuk dari kejadian banjir di DKI Jakarta, yaitu pada tahun 1996 dan 2002. Hal tersebut terjadi kembali pada 2 Februari 2007 dimana banjir besar terulang, yang diakibatkan oleh besarnya curah hujan di wilayah Jakarta Barat, Jakarta Pusat dan Jakarta Utara (Gernowo \& Yulianto, 2010)

Berkaitan dengan hal tersebut, tujuan dari penulisan karya tulis ini diantaranya adalah untuk menganalisis faktor-faktor penyebab kejadian El Nino Tahun 2015/2016 serta untuk mengetahui pengaruh dari kejadian El Nino terhadap intensitas curah hujan Wilayah Jabodetabek selama periode puncak musim hujan Tahun 2015/2016.

\subsection{Curah Hujan}

Hujan adalah salah satu bentuk presipitasi. Presipitasi merupakan pengendapan air dari atmosfer pada permukaan bumi dalam bentuk cair (tetes hujan) dan padat (salju). Di wilayah tropis seperti Indonesia presipitasi lebih didefinisikan sebagai hujan karena sangat jarang terjadi presipitasi dalam bentuk jatuhan butiran es. Jumlah curah hujan di catat dalam inci atau milimeter (1 inci $=25,4 \mathrm{~mm}$ ). Jumlah curah hujan $1 \mathrm{~mm}$ menunjukkan tinggi air hujan yang menutupi permukaan bumi setebal $1 \mathrm{~mm}$, jika air tersebut tidak meresap ke dalam tanah atau menguap ke atmosfer (Tjasyono, 2008).

Curah Hujan mempunyai variabilitas yang besar dalam ruang dan waktu. Dalam skala ruang, variabilitasnya sangat dipengarui oleh letak geografis, topografi, arah angin dan letak lintang. Dalam skala waktu keragaman curah hujan dibagi atas tipe harian, bulanan, dan tahunan. Variasi curah hujan harian lebih dipengarui oleh faktor lokal, variasi bulanan dipengarui oleh angin darat dan angin laut, aktivitas konveksi, arah aliran udara di permukaan serta variasi sebaran daratan dan lautan. Sedangkan variasi curah hujan tahunan dipengarui oleh perilaku atmosfer global, siklon tropis, dan lain-lain. Secara umum curah hujan di Indonesia di dominasi oleh pengaruh beberapa fenomena seperti sistem monsoon AsiaAustralia, El Nino/ La Nina, Sirkulasi Timur-Barat (Walker Circulation), Sirkulasi Utara-Selatan (Hadley Circulation), serta beberapa sirkulasi karena faktor lokal (Prasetya, 2011).

\subsection{El Nino}

El Nino secara ilmiah diartikan sebagai fenomena global dari sistem interaksi laut dan atmosfer yang ditandai dengan meningkatnya suhu muka laut atau SST (Sea Surface Temperature) di sekitar Pasifik Tengah dan Timur sepanjang equator dari nilai rata-ratanya. Pada tahun-tahun normal, suhu muka laut di sebelah Utara dan Timur Laut Australia bernilai $\geq$ $28^{\circ} \mathrm{C}$ sedangkan suhu muka laut di Samudra Pasifik sekitar Amerika Selatan bernilai $\pm 20^{\circ} \mathrm{C}$ (Tongkukut, 2011).

Dalam kondisi normal tersebut, angin equatorial berhembus ke arah barat membantu proses konveksi di Pasifik Barat dan subsidensi di Pasifik Timur. Sel sirkulasi vertikal tersebut disebut sebagai sirkulasi Walker (Gambar 1 bagian atas), dimana terjadi gerak naik di bagian Barat dan turun di Timur Samudra Pasifik Tropis dengan pergerakan ke arah Timur di Troposfer atas.

Perubahan kecil pada pola normal suhu permukaan laut di Samudra Pasifik Tropis bagian Barat akan menyebabkan perubahan angin musiman permukaan laut ke arah Timuran sepanjang equator. Perubahan angin biasanya terlihat sebagai anomali baratan yang menguatkan pertumbuhan anomali suhu permukaan laut dan angin kemudian akan merambat ke arah Timur untuk meningkatkan kondisi El Nino.

Selama fase dewasa El Nino, anomali sirkulasi Warker muncul berlawanan dengan kondisi normalnya, konveksi di bagian Barat di tekan dan konveksi dibagian Timur menguat (Gambar 1 bagian bawah). Setelah konveksi menurun di Samudra Pasifik Tropis bagian Barat, El Nino akan menyebabkan kondisi yang lebih kering di wilayah Indonesia pada umumnya (Fadholi, 2013).
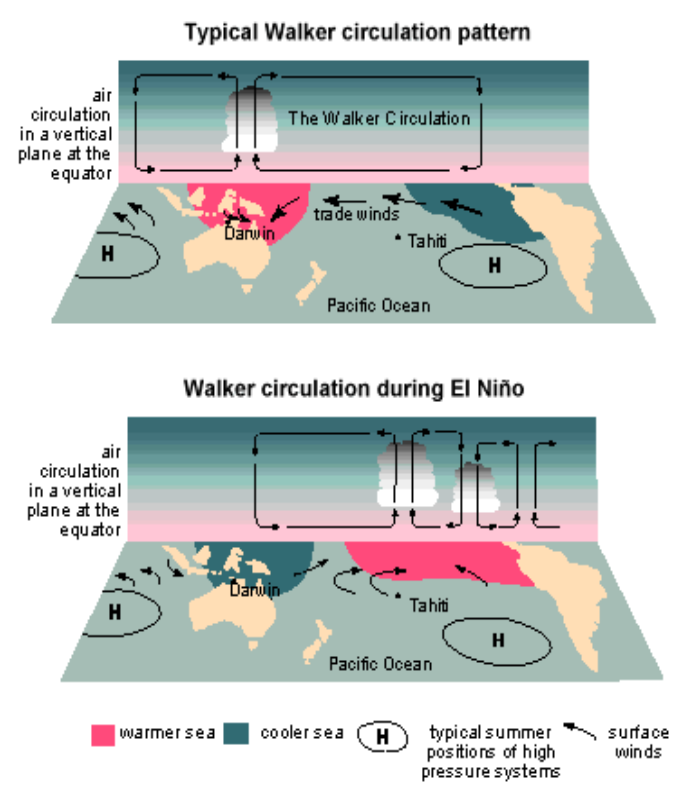

Gambar 1. Pola Sirkulasi Walker pada keadaan normal (atas) dan keadaan El Nino (bawah). 


\subsection{Sea Surface Temperature (SST)}

Suhu Permukaan Laut atau Sea Surface Temperature (SST) di perairan Indonesia sebagai indeks banyaknya uap air pembentuk awan di atmosfer. Jika suhu muka laut dingin uap air di atmosfer menjadi berkurang, sebaliknya jika suhu muka laut panas akan ada banyak uap air di atmosfer. Pola suhu muka laut di Indonesia secara umum mengikuti gerak tahunan matahari. Suhu muka laut di Samudra Hindia mempunyai rentang perubahan yang cukup lebar yaitu minimum berkisar $26,0^{\circ} \mathrm{C}$ pada bulan Agustus dan maksimum berkisar $31.5^{\circ} \mathrm{C}$ pada bulan Februari-Maret. Sedangkan wilayah perairan lainnya di Indonesia umumnya mempunyai rentang perubahan lebih sempit yaitu berkisar $29^{\circ} \mathrm{C}$ hingga $31.5^{\circ} \mathrm{C}$ dan waktu terjadinya suhu minimal dan maksimalnya tidak sama di setiap perairan (Ardhitama, 2015).

\subsection{Southern Oscillation Index (SOI)}

Southern Oscillation Index (SOI) juga merupakan salah satu indeks ENSO (EI Nino/ La Nina) dengan melihat perubahan anomali SLP (Sea Level Pressure) di Tahiti dan di Darwin. Ketika SOI positif (+) merupakan indikasi terjadinya La Nina, tandanya SLP di daerah sekitar Darwin berada lebih rendah daripada normalnya, sedangkan di Tahiti SLP nya lebih tinggi dibanding normalnya sehingga gerakan Timuran akan menguat dan membuat kolam panas mengumpul di Darwin. Sedangkan ketika SOI negatif (-) merupakan indikasi terjadinya EI Nino, dimana kondisi SLP di Darwin lebih besar dibandingkan normalnya, sedangkan SLP di daerah Tahiti lebih rendah dibanding normalnya.

\subsection{Pola Angin}

Pola angin yang sangat berpengaruh di Indonesia adalah Angin Muson (angin musim), hal ini disebabkan karena Indonesia terletak diantara Benua Asia dan Australia dan diantara Samudra Pasifik dan Samudra Hindia. Menurut Wyrtki (1961) pada dasarnya keadaan musim di Indonesia terbagi menjadi tiga, yaitu :

\section{Musim Barat}

Musim Barat (Muson Barat) terjadi pada bulan Oktober hingga Februari, pada periode ini matahari berada di belahan bumi selatan, mengakibatkan belahan bumi Selatan khususnya Australia lebih banyak memperoleh pemanasan matahari daripada benua Asia. Akibatnya di Australia bertemperatur tinggi dan tekanan udaranya rendah (minimum). Sebaliknya di Asia yang mulai ditinggalkan matahari temperaturnya rendah dan tekanan udaranya tinggi (maksimum). Oleh karena itulah terjadi pergerakan angin dari benua Asia ke benua Australia. Angin dari benua Asia ini akan dibelokkan oleh gaya Coriolis pada saat melintasi Khatulistiwa dan terbentuklah angin monsun baratan. Dikarenakan angin ini melewati Samudra Pasifik dan Samudra Indonesia serta Laut Cina Selatan sehingga angin ini akan membawa banyak uap air dan mengakibatkan adanya curah hujan yang cukup tinggi terutama di wilayah Indonesia bagian Barat.

b) Boreal Winter

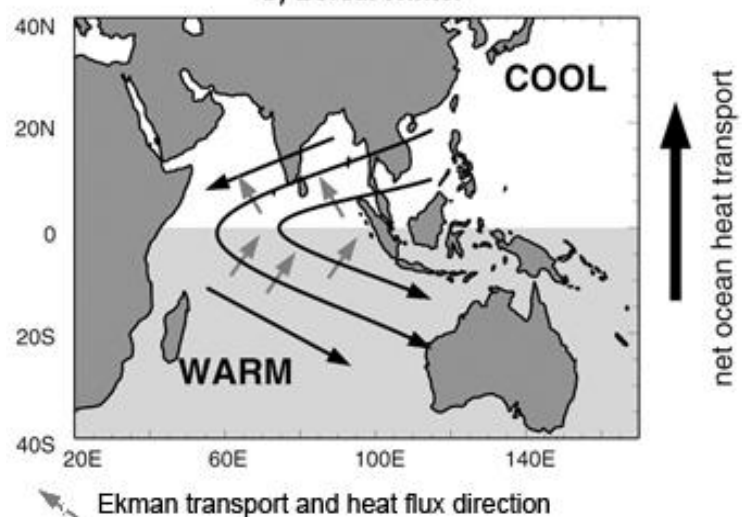

Gambar 2. Pola pergerakan angin Monsun Barat.

\section{Musim Timur}

Musim Timur (Muson Timur) terjadi pada bulan April hingga Agustus ketika matahari bergeser ke belahan bumi Utara. Di belahan bumi Utara khususnya Benua Asia termperaturnya menjadi tinggi dan tekanan udaranya rendah (minimum), sebaliknya di Benua Australia yang telah ditinggalkan matahari, temperaturnya rendah dan tekanan udaranya tinggi (maksimum). Sehingga terjadilah pergereakan angin dari benua Australia ke Benua Asia melalui Indonesia. Angin ini tidak banyak membawa uap air atau menurunkan hujan karena hanya melewati laut kecil dan jalur sempit seperti Laut Timor, Laut Arafuru, dan sebagian selatan Irian Jaya dan Nusa Tenggara.

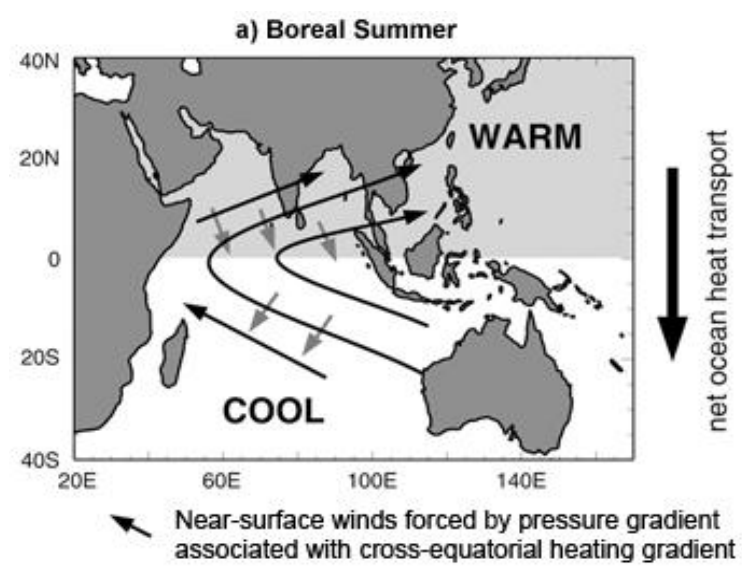

Gambar 3. Pola pergerakan angin Monsun Timur.

\section{Musim Peralihan}

Pada musim peralihan matahari bergerak melintasi khatulistiwa sehingga angin menjadi lemah dan arahnya tidak menentu. Periode Maret sampai April dikenal sebagai Musim Peralihan I 
(periode awal musim kemarau) sedangkan periode September hingga Oktober disebut sebagai musim Peralihan II (periode awal musim penghujan).

\section{METODE}

Daerah kajian pada penelitian ini adalah wilayah Jabodetabek, dimana wilayah ini identik dengan kejadian banjir untuk setiap tahunnya. Data yang digunakan pada penelitian ini meliputi data curah hujan bulanan dari tahun 1998-2016 dari satelit TRMM (Tropical Rainfall Measuring Mission) 3B43 v7 yang didapat dari situs NASA Giovanni dengan resolusi spasial $0.25^{\circ}$, Indek anomali Kejadian EI Nino berupa NINO3.4 tahun 2015-2016 yang didapat dari Badan Meteorologi Australia (BoM), data peta SST (Sea Surface Temperature) wilayah Samudra Pasifik Tropis yang didapat dari Jet Propulsion Laboratory (JPL) NASA dengan resolusi spasial $1 \mathrm{~km}$, dan juga data gradien wind wilayah Samudra Pasifik Tropis yang juga didapatkan dari situs NASA Giovanni.

Analisis kejadian El Nino Tahun 2015/2016 dilakukan dengan menganalisis nilai NINO 3.4 SST Index, Southern Oscillation Index (SOI) Indian Ocean Dipole (IOD), pola sebaran suhu permukaan laut (Sea Surface Temperature) dan juga gradient wind di Samudra Pasifik Tropis. Selanjutnya dilakukan analisis keterkaitan antara parameter-parameter ENSO tersebut dengan intensitas curah hujan rata-rata bulanan di wilayah Jabodetabek terutama pada saat puncak musim hujan Tahun 2015/2016. Pada penelitian ini juga akan dilakukan analisis spasial distribusi anomali curah hujan bulanan di wilayah Jabodetabek untuk lebih mengetahui karakteristik spasial pengaruh kejadian El Nino Tahun 2015/2016 terhadap intensitas curah hujan pada saat puncak musim hujan Tahun 2015/2016 di Wilayah Jabodetabek.

\section{HASIL DAN PEMBAHASAN}

\subsection{SST, Nino 3.4 dan SOI}

Kejadian Fenomana El Nino dan La Nina dapat dilihat dari suhu permukaan laut atau Sea Surface Temperature (SST), indeks anomali SST berupa NINO 3.4 SST Index, dan dari indeks Osilasi Selatan atau Southern Oscillation Index (SOI). Dimana NINO 3.4 SST Indeks ini merujuk pada besar perubaan/ anomali suhu muka laut di kawasan pasifik tengah dari nilai rata-ratanya dalam kurun waktu jangka panjang. Sedangkan SOI merujuk pada perubahan anomali Sea Level Pressure (SLP) di Tahiti dan di Darwin (Vitri \& Marzuki, 2014).

Ukuran-ukuran besaran nilai NINO 3.4 SST dan SOI yang dapat dijadikan dasar untuk pendugaan kejadian ENSO (El Nino/ La Nina) dapat dilihat pada Tabel 1 dan Tabel 2. Dimana
El Nino kuat terjadi jika anomali SST $>1.5^{\circ} \mathrm{C}$ dan indeks SOI $<-10$. La Nina kuat terjadi jika anomali SST $<-1.5^{\circ} \mathrm{C}$ dan indek SOI $>10$. Normal jika anomali SST antara $-0.5^{\circ} \mathrm{C}$ hingga $0.5^{\circ} \mathrm{C}$ dan indek SOI antara -5 hingga 5 . Kejadian tersebut harus berlangsung selama minimal 3 bulan.

Tabel 1. Klasifikasi Fenomena El Nino dan La Nina berdasarkan NINO 3.4 SST Index.

\begin{tabular}{|l|l|}
\hline \multicolumn{1}{|c|}{ NINO 3.4 SST Index } & \multicolumn{1}{|c|}{ Fenomena } \\
\hline$>+1.5^{\circ} \mathrm{C}$ & El Nino Kuat \\
\hline$+1.0^{\circ} \mathrm{C}$ s.d $+1.5^{\circ} \mathrm{C}$ & El Nino Sedang \\
\hline$+0.5^{\circ} \mathrm{C}$ s.d $+1.0^{\circ} \mathrm{C}$ & El Nino Lemah \\
\hline$-0.5^{\circ} \mathrm{C}$ s.d $+0.5^{\circ} \mathrm{C}$ & Netral \\
\hline$-1.0^{\circ} \mathrm{C}$ s.d $-0.5^{\circ} \mathrm{C}$ & La Nina Lemah \\
\hline$-1.5^{\circ} \mathrm{C}$ s.d $-1.0^{\circ} \mathrm{C}$ & La Nina Sedang \\
\hline$<-1.5^{\circ} \mathrm{C}$ & La Nina Kuat \\
\hline \multicolumn{2}{|c|}{ Sumber : BMKG Indonesia } \\
\hline
\end{tabular}

Tabel 2. Klasifikasi Fenomena EI Nino and La Nina berdasarkan Southern Oscillation Index (SOI).

\begin{tabular}{|l|l|}
\hline \multicolumn{1}{|c|}{ SOI } & \multicolumn{1}{c|}{ Fenomena } \\
\hline$<-10$ & El Nino Kuat \\
\hline-10 s.d -5 & El Nino Lemah-Sedang \\
\hline-5 s.d +5 & Netral \\
\hline+5 s.d +10 & La Nina Lemang-Sedang \\
\hline$>+10$ & La Nina Kuat \\
\hline \multicolumn{2}{|c|}{ Sumber : BMKG Indonesia }
\end{tabular}

Grafik data NINO 3.4 SST Index dan Southern Oscilation Index (SOI) yang didapat dari Bureau of Meteorology (BoM) direpresentasikan pada Gambar 4. Berdasarkan grafik NINO 3.4 SST Index tersebut dapat diketahui bahwa pada pada bulan November 2015 hingga bulan Februari 2016 telah terjadi fenomena El Nino kuat dengan nilai NINO 3.4 SST Index rata-rata diatas $2.5^{\circ} \mathrm{C}$ dan puncaknya pada bulan November 2015 dengan NINO 3.4 SST Index mencapai sekitar $2.95^{\circ} \mathrm{C}$.

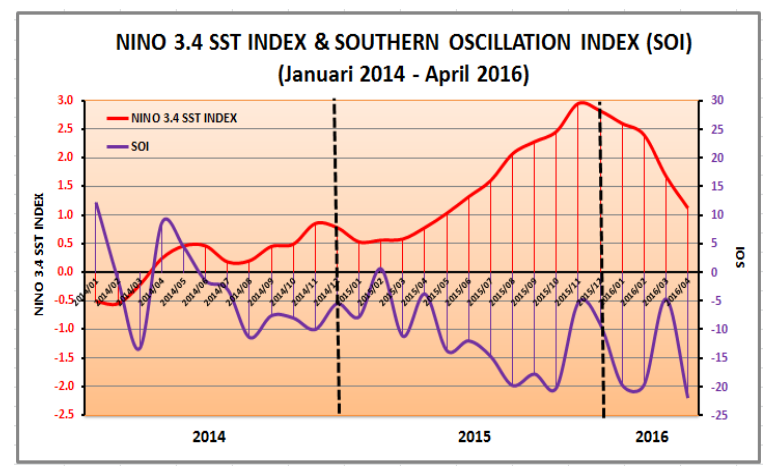

Gambar 4. Grafik NINO 3.4 SST Index dan Southern Oscilation Index, Januari 2014 - April 2016. 

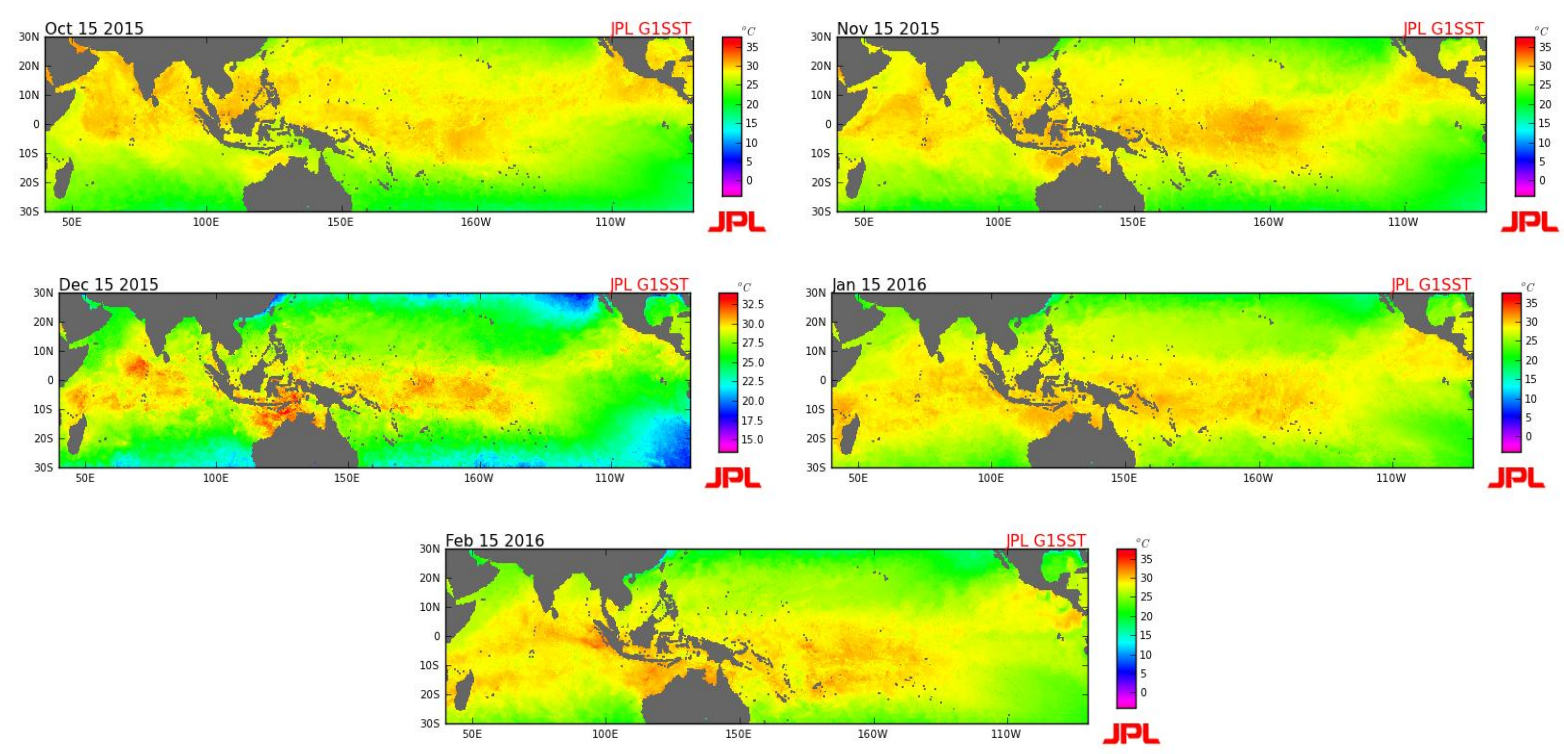

Gambar 5. Peta suhu permukaan laut wilayah perairan Indonesia, Samudra Pasifik dan Samudra Hindia bulan Oktober 2015 - Februari 2016.

Sedangkan berdasarkan Grafik data Southern Oscilation Index (SOI) yang juga direpresentasikan pada Gambar 4 dapat diketahui bahwa selama tahun 2015 bahkan hingga awal tahun 2016 nilai SOI relatif bernilai minus (-) yang menandakan Sea Level Pressure (SLP) di Darwin lebih besar dibandingkan dengan normalnya, sedangkan SLP di Tahiti lebih rendah dibandingkan dengan normalnya sehingga dikarenakan hal tersebut gerakan timuran akan melemah dan akan mendukung kolam panas mengumpul di daerah sekitar Tahiti atau Samudra Pasifik bagian Tengah.

Nilai SOI konstan bernilai $<-10$ dari bulan Mei hingga Oktober 2015, dimana nilai SOI yang terendah ada pada bulan Oktober 2015 dengan nilai SOI sebesar -20.2. Nilai SOI tersebut sempat naik hingga -5 pada November 2015 dan menurun kembali hingga berkisar -20 pada bulan Januari-Februari 2016. Jadi berdasarkan SOI tersebut dapat diketahui dari bulan Mei hingga Oktober 2015 telah terjadi El Nino pada level kuat, menurun pada level El Nino Sedang pada Bulan November-Desember 2015 dan naik

\subsection{Indian Ocean Dipole (IOD)}

Indeks IOD (Indian Ocean Dipole) atau Indeks DM (Dipole Mode) didefinisikan sebagai beda anomali temperature permukaan laut Samudra Hindia bagian Timur dengan Samudra Hindia bagian Barat, dimana nilai indeks IOD > 0.4 digolongkan sebagai IOD (+) dan indeks IOD $<-0.4$ digolongkan sebagai IOD (-).

IOD (+) artinya temperatur permukaan laut di pantai timur Afrika lebih tinggi daripada suhu permukaan laut di pantai Barat Sumatera, sebaliknya adalah IOD (-). Dengan demikian IOD (+) merupakan fase dingin laut pantai Barat Sumatera, sehingga konveksi melemah, sebaliknya IOD (-) adalah fase panas laut pantai kembali pada level El Nino Kuat pada bulan Januari-Februari 2016.

Peta Suhu Permukaan Laut Wilayah Perairan Indonesia, Samudra Pasifik dan Samudra Hindia Bulan Oktober 2015 - Februari 2016 direpresentasikan pada Gambar 5. Berdasarkan Peta Suhu Permukaan Laut tersebut dapat diketahui bahwa mulai Bulan November 2015 telah terjadi peningkatan Suhu Permukaan Laut yang cukup signifikan di sebagian besar perairan Indonesia dibandingkan pada periode bulan Juli-Oktober yang menjadi puncak musim kemarau berkepanjangan di sebagian besar wilayah Indonesia. Pada Bulan November 2015 hingga Februari 2016 walaupun anomali SST di Samudra Pasifik bagian Tengah (NINO 3.4) ada pada puncak tertingginya, akan tetapi suhu permukaan laut di sebagian besar perairan laut Indonesia sudah mulai meningkat sehingga memicu adanya pertumbuhan awan yang menyebabkan turunnya hujan di dengan intensitas sedang hingga tinggi di sebagian besar wilayah Indonesia termasuk di wilayah Jabodetabek.

Barat Sumatera sehingga konveksi menguat yang mengakibatkan adanya peningkatan curah hujan di wilayah Barat Indonesia selama fase IOD (-) tersebut.

Berdasarkan grafik tersebut dapat diketahui bahwa pada bulan Januari hingga Maret 2015 IOD Index masih relatif pada posisi negatif (-) artinya walaupun sudah ada gejala fenomena El Nino sejak awal tahun 2015, akan tetapi pembentukan awan di wilayah Indonesia terutama di wilayah Indonesia bagian Barat masih terbantu dengan adanya fase panas di perairan laut sebelah Barat Sumatera sehingga di wilayah Indonesia bagian Barat masih banyak curah hujan walupun di bawah intensitas ratarata curah hujan historisnya. 


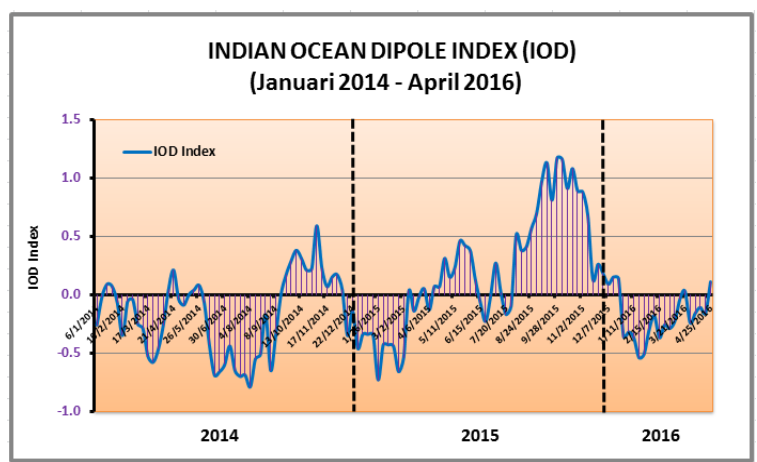

Gambar 6. Grafik Indian Ocean Dipole Index, Januari 2014 - April 2016.

Pada Bulan Juli 2015 IOD Index sudah relatif pada posisi positif $(+)$ dan puncaknya pada akhir bulan September 2015 IOD Index mencapai (+) 1.17 yang mengindikasikan temperatur permukaan laut di pantai Timur Afrika lebih tinggi daripada suhu permukaan laut di pantai Barat Sumatera, sehingga konveksi di pantai Barat Sumatera akan melemah dan hal tersebut akan semakin memperparah efek dari fenomana El Nino yang ada pada level kuat terutama pada bulan Juli hingga Oktober 2015.

Pada Bulan Desember 2015 IOD Index berangsur menurun dan awal Tahun 2016 IOD Index telah ada pada posisi negatif (-), hal tersebut akan membantu dalam peningkatan curah hujan di sebagian besar wilayah Indonesia termasuk wilayah Jabodetabek walaupun dari bulan Januari hingga Maret 2016 El Nino masih dalam level kuat.

\subsection{Gradient Wind}

Salah satu faktor yang mempengarui curah hujan di Indonesia adalah pola angin, dimana Peta Pola Angin (Gradient Wind) Wilayah Indonesia dari Bulan Oktober 2015 hingga Bulan Februari 2016 direpresentasikan pada Gambar 7.

Berdasarkan Gambar 7 tersebut dapat diketahui bahwa pada Bulan Oktober 2015 yang termasuk dalam musim peralihan, angin di sebagian besar wilayah Indonesia masih didominasi oleh angin Timuran sehingga hal ini akan mengakibatkan masa udara yang kering dari Benua Australia akan dibawa ke wilayah Indonesia, sehingga pada Bulan Oktober 2015

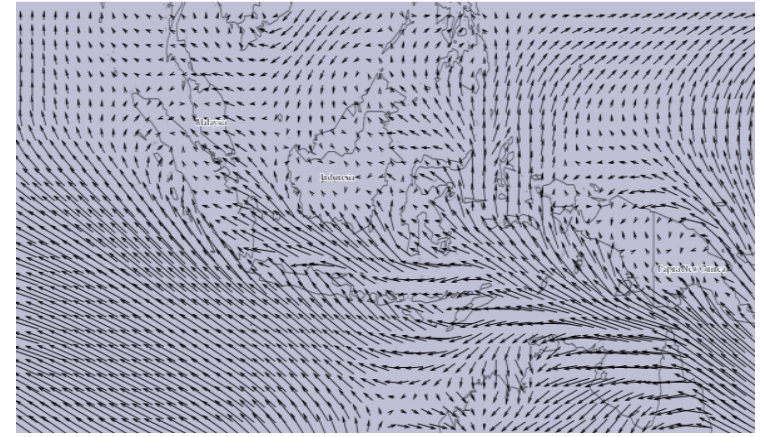

Oktober 2015

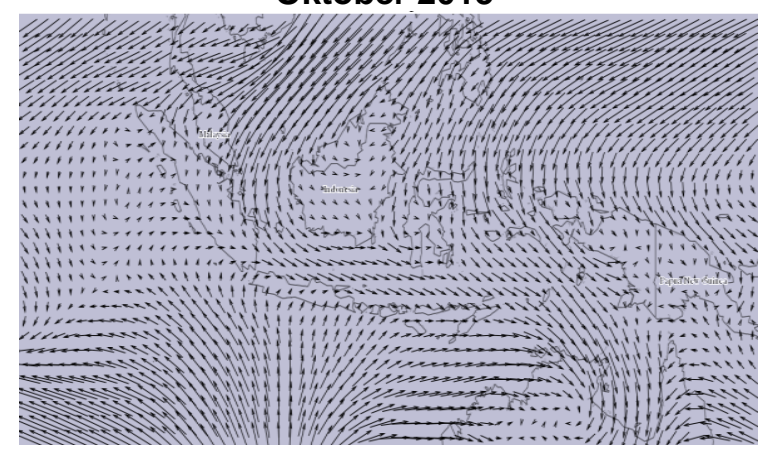

Desember 2015

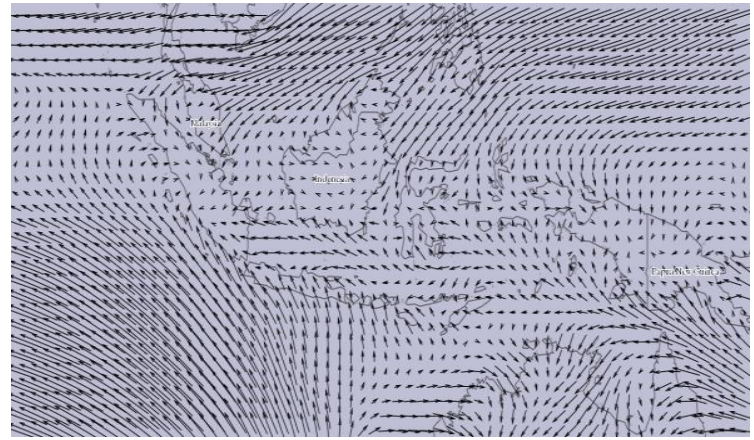

November 2015

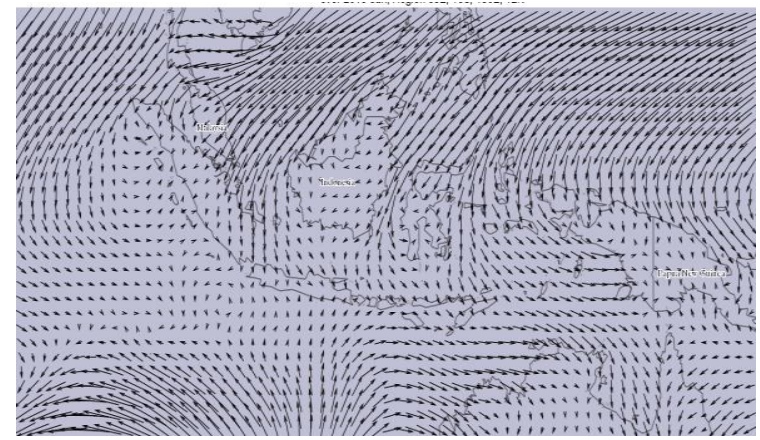

Januari 2016

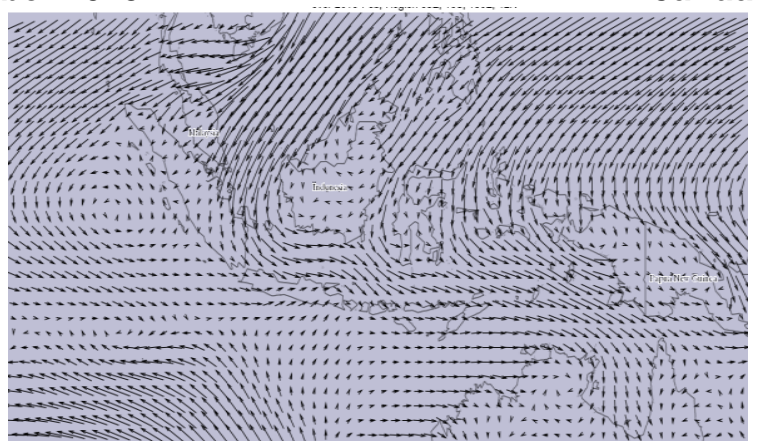

Februari 2016

Gambar 7. Peta gradient wind wilayah Indonesia bulan Oktober 2015 - Februari 2016. 
tersebut sebagian besar wilayah Indonesia masih dalam musim kemarau/ kering. Sedangkan pada Bulan November 2015 angin di wilayah Indonesia terbagi dua, dimana wilayah Indonesia dibawah lintang $0^{\circ}$ masih didominasi oleh angin Timuran sedangkan wilayah Indonesia di atas garis lintang $0^{\circ}$ sudah didominasi oleh angin Baratan. Hal ini akan menyebabkan wilayah Indonesia bagian Utara penambahan intensitas curah hujannya akan lebih besar/ signifikan dibandingkan dengan wilayah Indonesia bagian Selatan termasuk wilayah Jabodetabek.

Pada Bulan Desember 2015 hingga Februari 2016 angin di Wilayah Indonesia sudah didominasi oleh angin Baratan, dimana angin ini membawa masa udara yang cukup basah dari Samudra Pasifik, Samudra Hindia, dan Laut Cina Selatan sehingga hal tersebut mengakibatkan adanya curah hujan yang cukup tinggi terutama di Wilayah Indonesia bagian Barat termasuk wilayah Jabodetabek.

\subsection{Intensitas Curah Hujan Wilayah Jabodetabek}

Adanya fenomena El Nino pada tahun 2015 hingga awal tahun 2016 telah berdampak secara langsung terhadap intensitas curah hujan di sebagian besar wilayah Indonesia termasuk di wilayah Jabodetabek. Gambar 8 menunjukkan grafik pola historis curah hujan tahunan di wilayah Jabodetabek pada tahun-tahun kejadian El Nino sedang dan kuat yaitu tahun 2002, 2009, 2015, dan 2016.

Berdasarkan grafik tersebut dapat diketahui bahwa fenomena El Nino tahun 2015 telah menyebabkan penurunan intensitas curah hujan rata-rata bulanan di wilayah Jabodetabek terutama dari Bulan Juni hingga Oktober 2015.

Adanya penurunan suhu permukaan laut di sebagian besar perairan Indonesia, bergesernya pusat tekanan rendah di Samudra Pasifik karena melemahnya angin timuran, serta Indeks Dipole Mode yang bernilai positif menjadi faktor utama penurunan curah hujan di wilayah Jabodetabek pada rentang waktu bulan Juni hingga bulan Oktober 2015 tersebut.

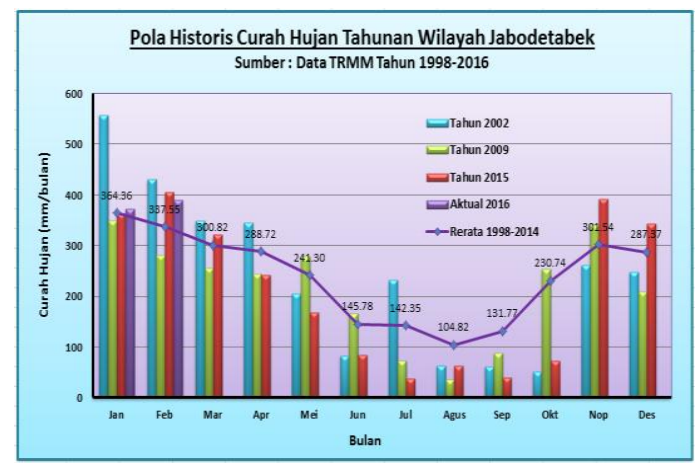

Gambar 8. Pola historis curah hujan tahunan wilayah Jabodetabek.

Berbeda dengan intensitas curah hujan bulan Juni hingga bulan Oktober 2015, curah hujan di wilayah Jabodetabek pada puncak musim hujan Tahun 2015/2016 (November 2015 hingga Februari 2016) cenderung normal dan bahkan beberapa bulan diatas nilai rata-rata curah hujan historisnya seperti yang juga direpresentasikan pada Gambar 9, dimana anomali curah hujan di wilayah Jabodetabek dari bulan November 2015 hingga Februari 2016 tersebut kecenderungannya beranomali positif.
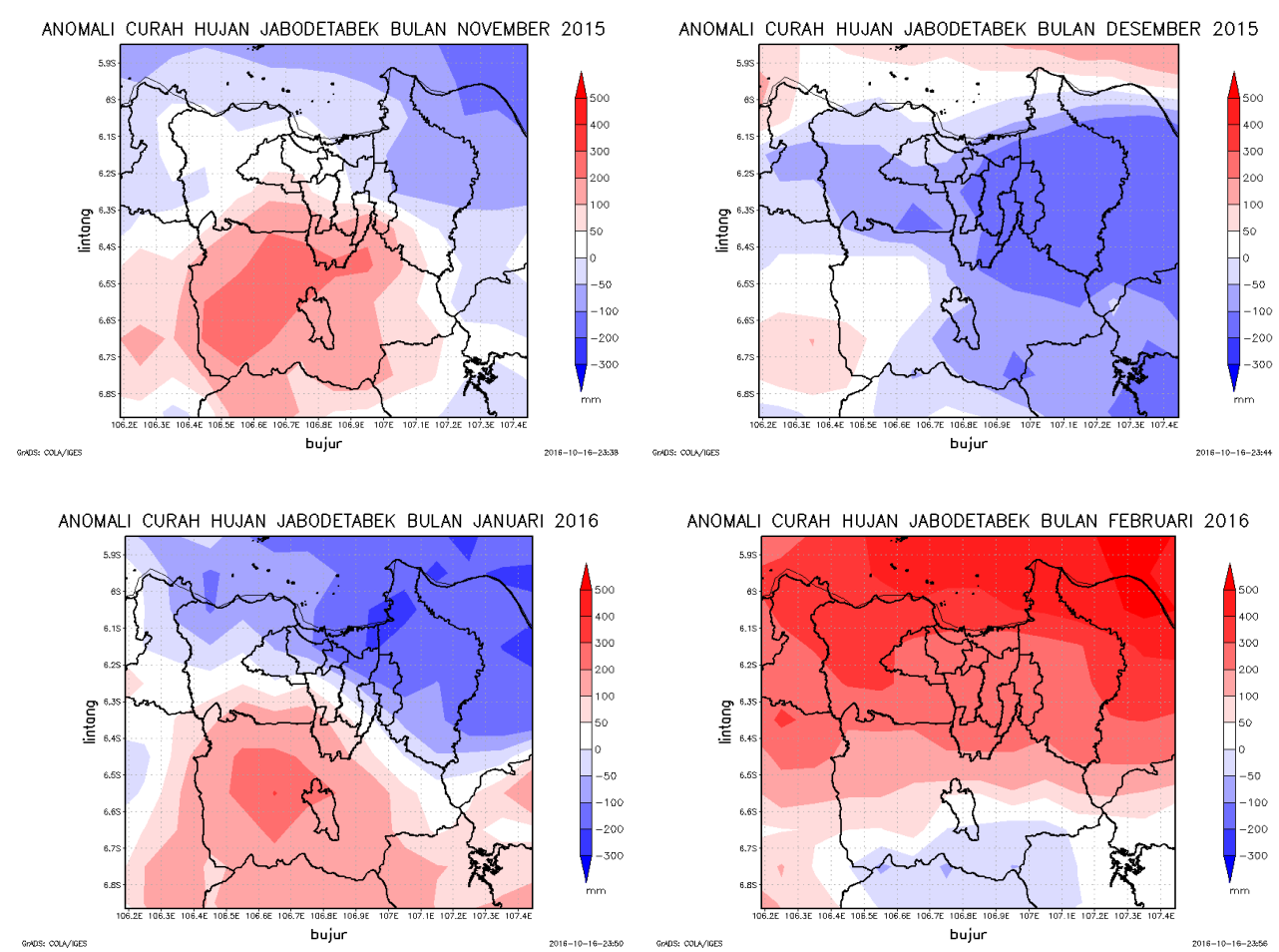

Gambar 9. Peta anomali curah hujan wilayah Jabodetabek bulan November 2015 - Februari 2016. 
Hal ini seperti yang dijelaskan pada pembahasan sebelumnya, walaupun dari bulan November 2015 hingga bulan Februari 2016 masih berada dalam level El Nino kuat, akan tetapi mulai bulan November 2015 sebagian besar perairan wilayah Indonesia telah mengalami peningkatan suhu permukaan laut sehingga Indeks Dipole Mode cenderung menurun dan menjadi bernilai negatif (-) sejak awal tahun 2016. Selain itu pada bulan November 2015 juga telah terjadi adanya peralihan Angin Muson Timur ke Angin Muson Barat di wilayah Indonesia sehingga hal ini akan mendukung proses konveksi di sebagian besar perairan Indonesia serta adanya massa udara basah yang dibawa masuk ke wilayah Indonesia dari Samudra Pasifik, Samudra Hindia, dan Laut Cina Selatan karena Angin Muson Baratan tersebut. Hal ini akan mengakibatkan peningkatan curah hujan di sebagian besar wilayah Indonesia secara signifikan termasuk di wilayah Jabodetabek.

Berdasarkan analisis data yang telah dilakukan dalam penelitian ini dapat diketahui bahwa El Nino kuat akan mempengaruhi intensitas curah hujan di wilayah Indonesia terutama di wilayah Indonesia bagian Barat termasuk wilayah Jabodetabek jika didukung dengan kondisi indeks IOD positif dan Angin Monsun Timur. Akan tetapi El Nino kuat tidak akan mempengaruhi intensitas curah hujan jika kondisi indeks IOD negatif dan terdapat Angin Monsun Barat seperti yang telah terjadi pada Puncak Musim Hujan Tahun 2015/2016 (November 2015 hingga Februari 2016).

\section{KESIMPULAN}

Berdasarkan parameter NINO 3.4 SST Index dan Southern Oscillation Index (SOI) dapat diketahui bahwa pada pertengahan Tahun 2015 hingga awal Tahun 2016 telah terjadi fenomana El Nino pada level kuat.

Adanya penurunan Suhu Permukaan Laut di sebagian besar perairan Indonesia, bergesernya pusat tekanan rendah di Samudra Pasifik karena melemahnya angin timuran, serta indeks Dipole Mode yang dalam nilai positif menjadi faktor utama penurunan curah hujan di wilayah Jabodetabek pada rentang waktu bulan Juni hingga bulan Oktober 2015.

Adanya peningkatan Suhu Permukaan Laut di sebagian besar wilayah Indonesia sejak bulan November 2015 yang diikuti dengan penurunan indeks Dipole Mode hingga menjadi bernilai negartif (-) sejak awal tahun 2016 serta dengan adanya peralihan Angin Muson Timur ke Angin Muson Barat di wilayah Indonesia telah menyebabkan peningkatan curah hujan yang cukup signifikan dalam batas normal di wilayah Jabodetabek pada puncak musim hujan Tahun 2015/2016 (November 2015 - Februari 2016) walaupun pada bulan November 2015 hingga
Februari 2016 tersebut masih berada pada level El Nino kuat.

El Nino kuat akan mempengaruhi intensitas curah hujan di wilayah Indonesia terutama di wilayah Indonesia bagian Barat termasuk wilayah Jabodetabek jika didukung dengan kondisi indeks IOD positif dan Angin Monsun Timur. Akan tetapi El Nino kuat tidak akan mempengaruhi intensitas curah hujan jika kondisi indeks IOD negatif dan terdapat Angin Monsun Barat seperti yang telah terjadi pada puncak musim hujan tahun 2015/2016 (November 2015 hingga Februari 2016).

\section{DAFTAR PUSTAKA}

Ardhitama, A. (2013). Model Simulasi Prakiraan Curah Hujan Bulanan pada Wilayah Riau dengan Menggunakan Input Data SOI, SST, NINO 3.4, dan IOD. Jurnal Sains \& Teknologi Modifikasi Cuaca, 14(2). 95-104.

Fadholi, A. (2013). Studi Dampak El Nino dan Indian Ocean Dipole (IOD) Terhadap Curah Hujan di Pangkalpinang. Jurnal IImu Lingkungan UNDIP, 11(1), 43-50. doi: 10.14710/jil.11.1.43-50

Irawan, B. (2006). Fenomena Anomali Iklim El Nino dan La Nino : Kecenderungan Jangka Panjang dan Pengaruhnya terhadap Produksi Pangan. Jurnal Forum Penelitian Agro Ekonomi, 24(1), 28-45. doi: 10.21082/fae.v24n1.2006.28-45

Gernowo, R., Yulianto, T. (2010). Fenomena Perubahan Iklim dan Karakteristik Curah Hujan Ekstrim di DKI Jakarta. Pertemuan IImiah XXIV HFI Jateng \& DIY, 13-18.

Gunawan, R. (2010). Gagalnya Sistem Kanal; Pengendalian Banjir Jakarta dari Masa ke Masa. Jakarta. Kompas Media Nusantara.

Marzuki, M., Kozu, T., Shimomai, T., Randeu, W.L., Hashiguchi, H., Shibagaki, Y. (2009). Diurnal Variation of Rain Attenuation Obtained From Measurement of Raindrop Size Distribution in Equatorial Indonesia. Journal of IEEE Transaction on Anntenas and Propagation, 57(4), 1191-1196 doi: 10.1109/TAP.2009.2015812

Martono, M. (2015). Dampak El Nino dan Indian Ocean Dipole 1997-1998 terhadap Intensitas Curah Hujan di Wilayah Pantai Utara dan Pantai Selatan Jawa. Prosiding Pertemuan IImiah XXIX HFI Jateng \& DIY 2015.

Mulyana, E. (2002). Pengaruh Dipole Mode Terhadap Curah Hujan di Indonesia. Jurnal Sains \& Teknologi Modifikasi Cuaca, 3(1), 39-43.

Prasetya, R. (2011). Analisis Curah Hujan Akibat Siklon Tropis Nangka, Parma dan Nida di Sulawesi Utara. Skripsi. Manado: Universitas Sam Ratulangi.

Tjasyono, B., Lubis, A., Juaeni, I., Ruminta., Harijono, S.W.B. (2008). Dampak Variasi 
Temperatur Samudra Pasifik dan Hindia Ekuatorial Terhadap Curah Hujan di Indonesia. Jurnal Sains Dirgantara, 5(2), 113.

Tongkukut, S.H.J. (2011). El Nino dan Pengaruhnya Terhadap Curah Hujan di Manado Sulawesi Utara. Jurnal IImiah Sains, 11(1), 102-108.

World Meteorological Organization. (2016). WMO Statement in the Status of the Global
Climate in 2015. Switzerland: World Meteorological Organization (WMO).

Wyrtki, K. (1961). Physical Oceanography of Southeast Asean Waters. Naga Report I. 2. California: The University of California.

Vitri, T., Marzuki. (2014) Analisis Pengaruh El Nino Southern Oscilation (ENSO) Terhadap Curah Hujan di Kota Tabang Sumatera Barat. Jurnal Fisika Unand, 3(4), 214-221. 